\title{
The American Phytopathological Society 2nd I.E. Melhus Graduate Student Symposium: New Frontiers in Plant Disease Losses and Disease Management
}

\author{
Stella Melugin Coakley
}

Department of Botany and Plant Pathology, Oregon State University, Corvallis 97331.

The I.E. Melhus Fund was established in The American Phytopathological Society Foundation with gifts from Dr. and Mrs. William C. Paddock, Mr. and Mrs. Walter Goeppinger, and Dr. and Mrs. Jack Wallin and enhanced by additional funds from the Foundation. Irving E. Melhus was a renowned teacher, an innovative researcher, and an outstanding departmental administrator at Iowa State University. His breadth of experience, contributions to the practical application of disease control, classic work on root pathogens of Iowa crops, and his visionary work on corn improvement epitomize a truly pioneer plant pathologist. In 1939, he coauthored the well-written textbook, The Elements of Plant Pathology, with Dr. G. C. Kent. His service to The American Phytopathological Society further exemplified his leadership in and commitment to the profession of phytopathology. He was president of APS in 1926 and was elected a Fellow in 1965. He was a member of the Iowa Academy of Sciences, the Botanical Society of America, and a Fellow of the American Association for the Advancement of Science. Dr. Melhus was not only an out- standing plant pathologist, he was an inspiring mentor and an engaging personality with a keen sense of humor.

Initially used to sponsor individual speakers (I.E. Melhus student speakers presented in 1997, 1998, and 2000), the first symposium, sponsored by the Epidemiology Committee, was funded in 1999. The second student speaker symposium, organized by the Plant Disease Losses Committee, was held in 2001. The papers published here are from those presented in the 2nd I.E. Melhus Student Symposium: New Frontiers in Plant Disease Losses and Disease Management at the APS meeting in August 2001. These speakers were chosen by a competitive process chaired by the Pacific Division Councilor. The responsibility for overseeing the selection process is being rotated alphabetically through the Divisions. The I.E. Melhus Fund has grown to the point that it will sponsor an annual student speaker symposium; effective for 2003, selection of the committees to organize the symposium will now be the responsibility of the APS Scientific Programs Board. 